Revista Brasileira de Farmacognosia Brazilian Journal of Pharmacognosy 22(2): 374-380, Mar./Apr. 2012

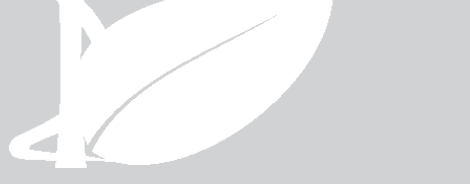

Article

Received 9 Jun 2011

Accepted 29 Aug 2011

Available online 29 Nov 2011

Keywords:

acetylcholinesterase inhibitors alkaloids

Conchocarpus fontanesianus

coumarin

Rutaceae

ISSN 0102-695X

http://dx.doi.org/10.1590/S0102-

695X2011005000219

\section{Anticholinesterase activity evaluation of alkaloids and coumarin from stems of Conchocarpus fontanesianus}

\author{
Rodrigo S. Cabral, ${ }^{1}$ Maura C. Sartori, ${ }^{1}$ Inês Cordeiro, ${ }^{2}$ Carmen \\ L. Queiroga, ${ }^{3}$ Marcos N. Eberlin, ${ }^{4}$ João H. G. Lago, ${ }^{5}$ Paulo R. \\ H. Moreno, ${ }^{6}$ Maria C. M. Young,
}

${ }^{I}$ Núcleo de Pesquisa em Fisiologia e Bioquímica, Instituto de Botânica de São Paulo, Brazil,

${ }^{2}$ Núcleo de Pesquisa Curadoria do Herbário São Paulo, Instituto de Botânica de São Paulo, Brazil,

${ }^{3}$ Centro Pluridisciplinar de Pesquisas Quimicas, Biológicas e Agrícolas, Universidade Estadual de Campinas, Brazil,

${ }^{4}$ Laboratório Thomson Espectrometria de Massa, Universidade Estadual de Campinas, Brazil,

${ }^{5}$ Departamento de Ciências Exatas e da Terra, Universidade Federal de São Paulo, Brazil;

${ }^{6}$ Instituto de Química, Universidade de São Paulo, Brazil.

\begin{abstract}
Conchocarpus fontanesianus (A. St.-Hill.) Kallunki \& Pirani, Rutaceae, popularly known as pitaguará, is a native and endemic tree from São Paulo and Rio de Janeiro States, Brazil. Based in the information that anticholinesterasic derivatives could act as new prototypes to treatment of Alzheimer disease, this work describes the fractionation guided by evaluation of the anticholinesterase activity of the ethanolic stems extract from $C$. fontanesianus. This procedure afforded the alkaloids dictamnine (1), $\gamma$-fagarine (2), skimianine (3), and 2-phenyl-1-methyl-4-quinolone (4), as well as the coumarin marmesin (5).
\end{abstract}

\section{Introduction}

The genus Conchocarpus (Rutaceae) comprises 45 species distributed in Central and South America (Kallunki \& Pirani, 1998). In Brazil, the genus can be found mainly in Amazonian, Atlantic Forrest and Cerrado regions (Pirani, 2010). Phytochemically, several constituents have been found in this genus, mainly alkaloids and flavonoids. Cortez et al. (2009) identified from the stems of $C$. gaudichaudianus four alkaloids, three indoloquinazolonic type and one quinoline type, along with two amides, $N$-trans-cumaroyltyramine, and $N$-trans-feruloyltyramine. Ambrozin et al. (2008) isolated from leaves of $C$. heterophyllus simple and hydroxylated flavones, and a mixture of new piranoflavones, while from the stems were isolated steroids, flavones, and alkaloids (haplotusine and 2-phenyl-1-methyl-4-quinolone). Additionally, from the leaves of $C$. paniculatus, Vieira et al. (1992) isolated two acridone alkaloids (cuspanine and cusculine).

Conchocarpus fontanesianus (A. St.-Hill.) Kallunki \& Pirani, Rutaceae, popularly known as pitaguará, is Brazilian native and endemic species, distributed in Atlantic Rain Forest, mainly in the states of São Paulo and Rio de Janeiro (Pirani, 2002). Despite of the antifungal, antitumoral, and antimicrobial activities from leaves extract has been already described (Agripino et al., 2004), there is no information about the phytochemicals isolated from this plant.

The Alzheimer disease (AD), a neurodegenerative disease of a great socioeconomic impact, is associated with deficits in brain neurotransmitters (Guela \& Mesulam, 1994). The symptomatic treatment of AD primarily involves restoration of cholinergic function (Francis et al., 1999; Trevisan, 2003). The inhibition of acetylcholinesterase (AChE) is the most effective therapeutic approach to optimize the cholinergic system in patients with AD. Several plant-derived drugs (rivastigmine and galanthamine) that inhibit $\mathrm{AChE}$ can be used to treat early stages of AD, since these compounds increase the endogenous levels of acetylcholine to boost cholinergic neurotransmission (Scott \& Goa, 2000). In a recent review, 260 chemically defined natural molecules were evaluated for AChE inhibition. The compounds tested were classified in alkaloids (139), monoterpenes 
(27), coumarins (18), triterpenes (17), flavonoids (14), benzenoids (13), diterpenes (8), oxygen heterocycles (5), sesquiterpenes (5), stilbenes (3), lignans (2), sulfur compounds (2), proteids (2), polycyclic (1), quinoid (1), benzoxazinone (1), carotenoid (1) and alycyclic (1) (Howes et al., 2003; Barbosa-Filho et al., 2006; Houghton et al., 2006). In this sense, the discovery of new compounds from natural sources with anticholinesterase activity is of great interest.

In continuation with trials conducted with native species of Cerrado and Atlantic Rain Forest, the crude ethanol (EtOH) extract from the stems of $C$. fontanesianus showed anticholinesterase potential. Thus, the aim of this work was perform the chemical study of the stems of $C$. fontanesianus, guided by inhibitory $\mathrm{AChE}$ activity assays.

\section{Material and Methods}

\section{General experimental procedures}

High performance liquid chromatography (HPLC) was performed using Varian Pro Star 310 with loop of $20 \mu \mathrm{L}$, detection in UV detector at $242 \mathrm{~nm}$, using mobile phase acetonitrile $(\mathrm{ACN})$, methanol $(\mathrm{MeOH})$ and deionized water $\left(\mathrm{H}_{2} \mathrm{O}\right.$, milli $\left.\mathrm{Q}\right)$ in the proportion of $10: 45: 45 \mathrm{v} / \mathrm{v}$ (isocratic mode) and a flow at $1 \mathrm{~mL} / \mathrm{min}$, during $30 \mathrm{~min}$. LC-MS (Liquid Chromatography/Mass Spectormetry) and LC-DAD (Liquid Chromatography/ Photodiode Array Detector) analyzes were recorded in a Shimadzu equipment, using a pump LC-10AD vp, UVVis detector SPD-M10A vp, SIL-10AF autosampler, and a Phenomenex Luna C-18 reverse phase column (250 x $4.6 \mathrm{~mm}-5 \mu$ ). Mass spectra obtained by HRESIMS (positive mode) were recorded in a Micromass QTof MS spectrometer (Manchester, UK), with the electrospray ionization source and TOF analyzer. The general conditions used were: source temperature $100{ }^{\circ} \mathrm{C}$, capillary voltage of $2.1 \mathrm{kV}$ and cone voltage of $40 \mathrm{~V}$. All data were obtained in positive mode $(+)$ and were treated using the software Mass Lynx 3.5 (Waters, Manchester, UK). The samples were dissolved in $\mathrm{MeOH}(100+0.1 \%$ $\left.\mathrm{HCO}_{2} \mathrm{H}\right)$ and analyzed by direct insertion. Analyses by GC-LREIMS (Gas Chromatography/Mass Spectrometry) were performed using a gas chromatography Agilent 6890 Series with an HP-5MS apolar column $(30 \mathrm{~m} \mathrm{x}$ $0.25 \mathrm{~mm}-0.25 \mu \mathrm{m}$ film thickness) coupled with mass spectrometer Agilent 5937 (electron impact ionization at $70 \mathrm{eV}$ ), ion source temperature of $230{ }^{\circ} \mathrm{C}$, with a quadrupole analyzer. Helium has used as carrier gas and general conditions were: initial temperature $100{ }^{\circ} \mathrm{C}(1$ min), increasing $15{ }^{\circ} \mathrm{C} / \mathrm{min}$ to $300{ }^{\circ} \mathrm{C}$, holding at 300 ${ }^{\circ} \mathrm{C}(10 \mathrm{~min})$. Preparative TLC were performed on glass plates of $20 \times 20 \mathrm{~cm}(0.5 \mathrm{~mm}$ thickness) of silica gel 60 $\mathrm{PF}_{254}$ (Merck).

\section{Plant material and extraction}

Stems of Conchocarpus fontanesianus (A. St.Hil.) Kallunki \& Pirani, Rutaceae, were collected at Ecological Station Jureia-Itatins (license SMA process $n^{\circ}$ 260.108-007.532 2009), Nucleus Arpoador/Peruíbe, São Paulo State, Brazil (24 22'58.5” S, $47^{\circ} 01^{\prime} 07.5^{\prime \prime}$ W, 38 $\mathrm{m}$ above sea level) and identified by Dra. Inês Cordeiro. A voucher specimen (RSCabral 09) has been deposited at the Herbário do Estado 'Maria Eneyda P. Kaufmann Fidalgo (SP)', São Paulo, SP, Brazil.

The powder of the stems of $C$. fontanesianus $(534.23 \mathrm{~g})$ was submitted to extraction with $\mathrm{EtOH}$ under pressure (1500-1700 psi) at $60{ }^{\circ} \mathrm{C}$ using an ASE300 extractor (DIONEX). The EtOH solution was concentrated in vacuum, to give crude EtOH extract (EE).

\section{Compounds isolation procedures}

EtOH extract $(14.53 \mathrm{~g})$ was partially dissolved in aqueous acid solution $(0.1 \mathrm{M} \mathrm{HCl})$, filtered and the soluble acid solution was partitioned with hexane, yielding the $n$-hexane fraction $(0.0963 \mathrm{~g})$. The acid aqueous fraction was treated with $\mathrm{NH}_{4} \mathrm{OH}(\mathrm{pH} 10)$ and partitioned with $\mathrm{CHCl}_{3}$ obtaining the alkaloid fraction $(0.3134 \mathrm{~g})$. All fractions were evaluated for their anticholinesterase potential.

The purification of alkaloid fraction was performed by prep TLC, eluted with $\mathrm{CHCl}_{3}: \mathrm{MeOH}: \mathrm{NH}_{4} \mathrm{OH}(90: 7.5: 2.5 \mathrm{v} / \mathrm{v})$. This procedure afforded a fraction composed by $\mathbf{1}+\mathbf{2}(26.5 \mathrm{mg})$, and compounds $\mathbf{3}(31.0 \mathrm{mg}), \mathbf{4}(27.7 \mathrm{mg})$, and $\mathbf{5}(35.2 \mathrm{mg})$.

Dicatmine (1). Yellow amorphous solid. HPLC $\mathrm{R}_{\mathrm{t}}=16.6$ min. UV $\lambda_{\max }(\log \varepsilon): 240$ (3.93), 311 (3.22). HRESIMS: $[\mathrm{M}+\mathrm{H}]^{+} \mathrm{m} / \mathrm{z}$ 200.0688, calc. to $\mathrm{C}_{12} \mathrm{H}_{10} \mathrm{O}_{2} \mathrm{~N} 200.0712$. LREIMS $m / z$ (int. rel.): $199\left(\mathrm{M}^{+}, 100\right), 184$ (72), 156 (36), 130 (19), 128 (36), 101 (26), 76 (25), 75 (20), 50 (17).

$\gamma$-Fagarine (2). Yellow amorphous solid. HPLC $\mathrm{R}_{\mathrm{t}}=14.7$ min. UV $\lambda_{\max }(\log \varepsilon): 242$ (4.78), 308 (3.81). HRESIMS: $[\mathrm{M}+\mathrm{H}]^{+} \mathrm{m} / \mathrm{z} 230.0814$, calc. to $\mathrm{C}_{13} \mathrm{H}_{12} \mathrm{O}_{3} \mathrm{~N} 230.0818$. LREIMS $m / z$ (int. rel.): $229\left(\mathrm{M}^{+}, 100\right), 228$ (82), 214 (34), 200 (83), 199 (36), 185 (26), 184 (31), 156 (41).

Skimiamine (3). Yellow amorphous solid. HPLC $\mathrm{R}_{\mathrm{t}}=12.5$ min. UV $\lambda_{\text {max }}(\log \varepsilon): 251$ (3.77), 328 (3.04). HRESIMS: $[\mathrm{M}+\mathrm{H}]^{+} \mathrm{m} / \mathrm{z}$ 260.0862, calc. to $\mathrm{C}_{14} \mathrm{H}_{13} \mathrm{O}_{4} \mathrm{~N} 260.0923$. LREIMS $\mathrm{m} / z$ (int. rel.): $259\left(\mathrm{M}^{+}, 61\right), 258$ (25), 244 (100), 230 (56), 229 (27), 228 (23), 216 (24), 213 (27), 201 (26), 199 (16).

2-Phenyl-1-methyl-4-quinolone (4). Yellow amorphous 
solid. HPLC $\mathrm{R}_{\mathrm{t}}=7.88$ min. HRESIMS: $[\mathrm{M}+\mathrm{H}]^{+} \mathrm{m} / z$ 236.1011, calc. to $\mathrm{C}_{16} \mathrm{H}_{14} \mathrm{ON} 236.1076$. LREIMS $\mathrm{m} / \mathrm{z}$ (int. rel.): $235\left(\mathrm{M}^{+}, 76\right), 207$ (100), 165 (19), 130 (11), 102 (18), 89 (17), 77 (37), 51 (25).

Marmesin (5). Yellow amorphous solid. HPLC $\mathrm{R}_{\mathrm{t}}=6.57$ $\min . \mathrm{UV} \lambda_{\max }(\log \varepsilon): 212$ (3.89), 335 (4.09). HRESIMS: $[\mathrm{M}+\mathrm{H}]^{+} \mathrm{m} / \mathrm{z}$ 247.0993, calc. to $\mathrm{C}_{14} \mathrm{H}_{15} \mathrm{O}_{4} 247.0971$ LREIMS $m / z$ (int. rel.): $246\left(\mathrm{M}^{+}, 28\right), 213$ (21), 188 (58), 187 (100), 160 (31), 131 (26), 77 (17), 59 (74), 51 (15), 43 (28).

\section{Inhibitory activity of acetilcholinesterase (IAChEs)}

\section{Qualitative evaluation procedure}

The AChE inhibitory activity of EtOH crude extract, alkaloid fraction, hexane fraction and purified compounds were detected using a TLC autographic assay as previously described (Marston et al., 2002). The TLC layers were spotted with 200, 100 and $50 \mu \mathrm{g}$ for crude extract, fractions and purified compounds, respectively, developed with $\mathrm{CHCl}_{3}: \mathrm{MeOH}: \mathrm{NH}_{4} \mathrm{OH}(90: 7.5: 2.5 \mathrm{v} / \mathrm{v})$ and subsequently dried. The plates were then sprayed with the enzyme solution $(6.66 \mathrm{U} / \mathrm{mL})$, thoroughly dried, and incubated at $37{ }^{\circ} \mathrm{C}$ for $20 \mathrm{~min}$ (moist atmosphere). Enzyme activity was detected by spraying with a solution consisting of $0.25 \%$ of 1-naphthyl acetate in EtOH plus $0.25 \%$ aqueous solution of Fast Blue B salt. Potential acetylcholinesterase inhibitors appeared as clear zones on a purple colored background. Electric eel AChE type $\mathrm{V}$ (product no. $\mathrm{C} 2888,1000 \mathrm{U}$ ) and the other reagents were purchased from Sigma-Aldrich.

\section{Quantitative evaluation}

A Biotek ELISA reader, model Power Wave, "KC4 software" was used to establish each reation rate. In each well of a 96-well microplate was added 25 $\mathrm{mL}$ acetylthiocholine iodide $(15 \mu \mathrm{M}), 125 \mu \mathrm{L}$ of $5,5^{\prime}$ ditiobis-[2-nitrobenzoic] in solution C (3 $\mu \mathrm{M}$ DTNB or Ellman's reagent), $50 \mu \mathrm{L}$ of solution $\mathrm{B}, 25 \mu \mathrm{L}$ of samples (EtOH crude extract, alkaloid fraction, $n$-hexane fraction and purified compounds) dissolved in $\mathrm{MeOH}$ and diluted in solution $\mathrm{A}$ at concentrations of $0.78-200 \mu \mathrm{g} / \mathrm{mL}$ (Rhee et al., 2001; Trevisan et al., 2003). The absorbance was measured at $405 \mathrm{~nm}$ for $30 \mathrm{~s}$. Then, $25 \mu \mathrm{L}$ of the enzyme AChE (0.22 U/mL) was added and absorbance was measured again after 5, 10, 15 and 20 min of incubation of the enzyme. The percentage of AChE inhibition was calculated by comparing the reaction rates (hydrolysis of the substrate) samples as compared to negative control $(10 \% \mathrm{MeOH}$ in the solution $\mathrm{A}$, considered the total activity of AChE, $100 \%$ ). The standard used as positive control was physostigmine at concentrations of 0.097 -
$200 \mu \mathrm{g} / \mathrm{mL}$. Solutions: A. Tris/HCl 50 mM, pH 8; B. Tris/ $\mathrm{HCl} 50 \mathrm{mM}$, pH 8, with $0.1 \%$ bovine albumin fraction $\mathrm{V}$; C. Tris/ $\mathrm{HCl} 50 \mathrm{mM}, \mathrm{pH} 8$, with $\mathrm{NaCl}(0.1 \mathrm{M})$ and $\mathrm{MgCl}_{2}$ $.6 \mathrm{H}_{2} \mathrm{O}(0.02 \mathrm{M})$ (Ellman et al., 1961 modified by Rhee et al., 2001).

\section{Statistical analysis}

Data were presented as means \pm SEM of experiments realized at least in triplicate. The IC50 values were calculated by means of regression analysis.

\section{Results and Discussion}

Partition of EtOH crude extract from stems of Conchocarpus fontanesianus (A. St.-Hil.) Kallunki \& Pirani, Rutaceae, gave $n$-hexane and alkaloid fractions ( 0.63 and $2.15 \%$ yield, respectively). The results of the TLC qualitative evaluation of the EtOH extract (EE), $n$-hexane (HEX), and alkaloid (ALK) fractions indicated that all presented AChE inhibitory potential, being more intense in hexane and alkaloid fractions (Figure 1). Similarly, in quantitative analysis, the EE extract, the HEX and ALK fractions inhibited AChE activity (Table 1 and Figure 2), being the greatest potential observed to ALK fraction (IC50 $31.73 \pm 0.45 \mu \mathrm{g} / \mathrm{mL}$ ).

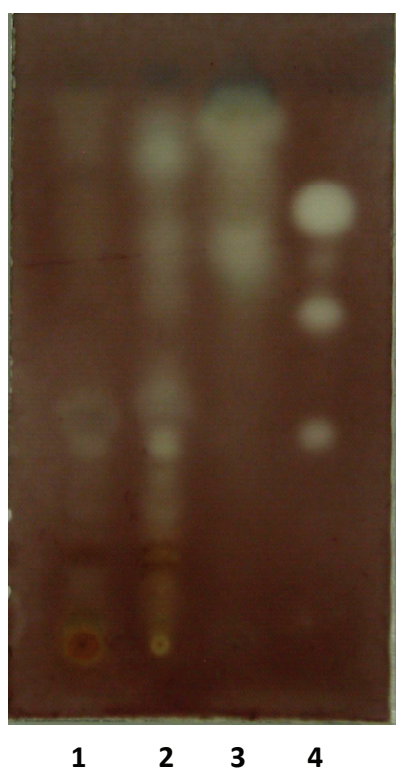

Figure 1. TLC qualitative acetylcholisterase assay. 1. EtOH crude extract $(200 \mu \mathrm{g}) ; 2$. Alkaloid fraction (100 $\mu \mathrm{g})$; 3. Hexane fraction $(100 \mu \mathrm{g})$, and 4 . Physostigmine $(0.05 \mu \mathrm{g})$. TLC elution system: $\mathrm{CHCl}_{3}: \mathrm{MeOH}: \mathrm{NH}_{4} \mathrm{OH}$, $90: 7.5: 2.5 \mathrm{v} / \mathrm{v}$.

The purification of the alkaloid fraction by preparative TLC afforded compounds 1-5. In the case of compounds 1-3, the absorption bands at $\lambda_{\max } 240$ - 
251 and $308-328 \mathrm{~nm}$, were indicative of furoquinoline alkaloids (Grundon \& McCorkindale, 1957; Cortez et al., 2006). HRESIMS showed ion peaks $[\mathrm{M}+\mathrm{H}]^{+}$at $\mathrm{m} / \mathrm{z} 200.0688,230.0814$ and 260.0862 corresponding, respectively, to molecular formulas $\mathrm{C}_{12} \mathrm{H}_{9} \mathrm{NO}_{2}$, $\mathrm{C}_{13} \mathrm{H}_{11} \mathrm{NO}_{3}$, and $\mathrm{C}_{14} \mathrm{H}_{13} \mathrm{NO}_{4}$. This information, associated with fragmentation patterns observed in GC-LREIMS and comparison with those described in the literature (Paulini et al., 1989; Inada et al., 2008; Li et al., 2011), allowed the identification of dictamnine (1), $\gamma$-fagarine (2) and skimianine (3). Compound 4 showed a ion peak $[\mathrm{M}+\mathrm{H}]^{+}$at $\mathrm{m} / \mathrm{z} 236.1011$ in the HRESIMS spectrum, corresponding to molecular formula $\mathrm{C}_{16} \mathrm{H}_{13} \mathrm{NO}$ and a fragmentation pattern characteristic of quinolone alkaloid (Biavatti et al., 2002). Comparison of MS data with those recorded in the literature, allowed its identification as 2-phenyl-1-methyl-4-quinolone (Ambrozin et al., 2008). UV spectrum of 5 showed absorptions at $\lambda_{\text {max }}$ at 212 and $335 \mathrm{~nm}$, characteristic of furanocoumarins (Abu-Mustafa \& Fayez, 1961; Joo et al., 2004). The ion peak $[\mathrm{M}+\mathrm{H}]^{+}$ at $\mathrm{m} / \mathrm{z} 247.0993$, corresponding to molecular formula $\mathrm{C}_{14} \mathrm{H}_{14} \mathrm{O}_{4}$, associated with LREIMS fragmentation pattern and comparison with literature data (Trumble \& Milla, 1996), allowed the identification of the compound $\mathbf{5}$ as marmesin.

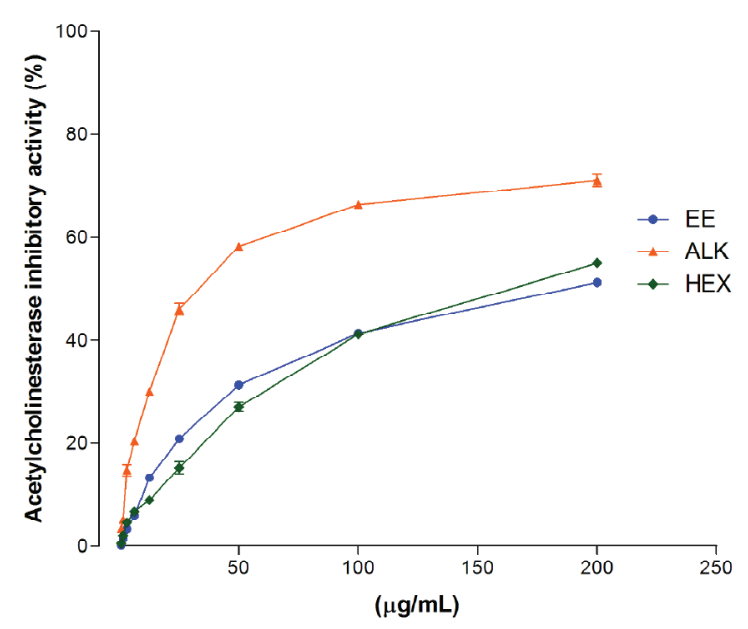

Figure 2. Acetylcholinesterase inhibitory potential of the EtOH crude extract (EE), alkaloid fraction (ALK) and hexane fraction (HEX) (0.78 to $200 \mu \mathrm{g} / \mathrm{mL})$.

Compounds 1-5 showed AChE inhibitory potential in the TLC qualitative (Figure 3) as well as in the quantitative assay, as shown in Table 2. TLC qualitative assay indicated that more actives compounds

Table 1. Acetylcholinesterase inhibitory potential of the EtOH crude extract, alkaloid fraction and hexane fraction $(0.78$ to $200 \mu \mathrm{g} /$ $\mathrm{mL}$ ).

\begin{tabular}{cccc}
\hline $\begin{array}{c}\text { Concentration } \\
(\mu \mathrm{g} / \mathrm{ml})\end{array}$ & $\begin{array}{c}\text { Ethanolic crude extract } \\
\text { \% of inhibition } \pm \text { SEM }\end{array}$ & $\begin{array}{c}\text { Alkaloid fraction } \\
\text { \% of inhibition } \pm \text { SEM }\end{array}$ & $\begin{array}{c}\text { Hexane fracion } \\
\text { \% of inhibition } \pm \text { SEM }\end{array}$ \\
\hline 0,78 & $0,169 \pm 0,089$ & $3.305 \pm 0,242$ & $0,450 \pm 0,238$ \\
1,56 & $1.435 \pm 0,206$ & $5.115 \pm 0,192$ & $2.025 \pm 0,192$ \\
3,12 & $3.253 \pm 0,18$ & $14.725 \pm 0,628$ & $4.520 \pm 0,139$ \\
6,25 & $5.883 \pm 0,079$ & $20.416 \pm 0,28$ & $6.663 \pm 0,05$ \\
12,50 & $13.234 \pm 0,425$ & $30.061 \pm 0,441$ & $8.966 \pm 0,108$ \\
25,00 & $20.852 \pm 0,326$ & $46.008 \pm 0,672$ & $15.190 \pm 0,698$ \\
50,00 & $31.248 \pm 0,723$ & $58.163 \pm 0,255$ & $26.997 \pm 0,494$ \\
100,00 & $41.356 \pm 0,631$ & $66.326 \pm 0,195$ & $41.159 \pm 0,31$ \\
200,00 & $51.234 \pm 0,518$ & $71.087 \pm 0,658$ & $54.945 \pm 0,224$ \\
\hline
\end{tabular}<smiles>COc1c2ccccc2nc2occc12</smiles>

1<smiles>COc1c2ccoc2nc2c(OC)cccc12</smiles>

2<smiles>COc1ccc2c(OC)c3ccoc3nc2c1OC</smiles>

3<smiles>Cn1c(-c2ccccc2)cc(=O)c2ccccc21</smiles>

4<smiles>CC(C)(O)[C@H]1Cc2cc3ccc(=O)oc3cc2O1</smiles>

5 
were furocoumarin (5) and quinolone alkaloid (4). In the quantitative assay the mixture of alkaloids dictamnine (1) and $\gamma$-fagarine (2) reduced the activity of AChE from $1.12 \pm 0.14$ to $52.0 \pm 0.2 \%$ while alkaloid skimmianine (3) reduced the activity from $0.98 \pm 0.26$ to $67.21 \pm 0.29 \%$. Similarly, alkaloid 2-phenyl-1-methyl-4quinolone (4) reduced the activity of AChE of $0.34 \pm 0.09$ to $48.60 \pm 0.23 \%$. Coumarin marmesin (5) reduced the activity from $0.61 \pm 0.13 \%$ to $52.87 \pm 0.25 \%$ (Figure 4 ).

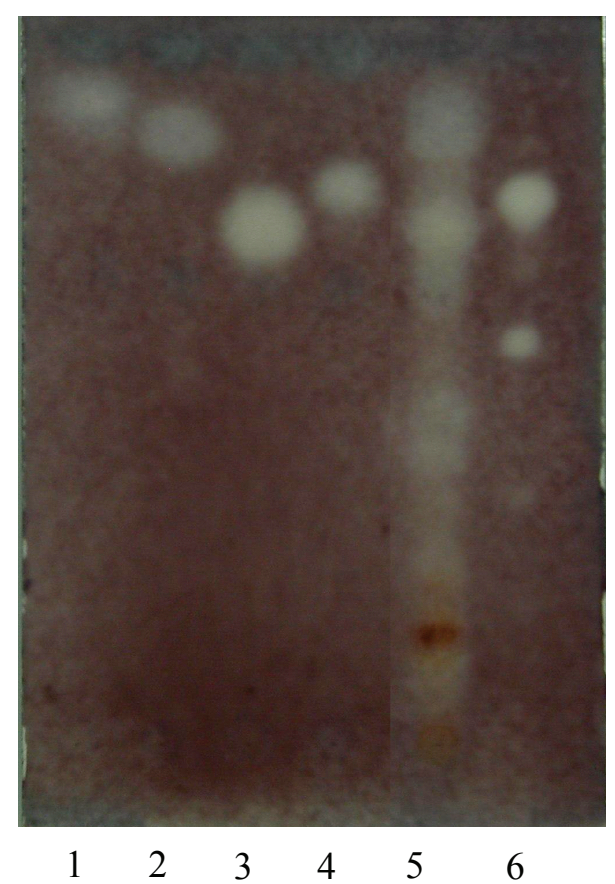

Figure 3. TLC qualitative acetylcholisterase assay. 1. dictamin $+\gamma$-fagarine $(50 \mu \mathrm{g}), 2$. skimianine $(50 \mu \mathrm{g}), 3$. marmesin $(50 \mu \mathrm{g}), 4$. 2-phenyl-1-methyl-4-quinolone $(50 \mu \mathrm{g})$, 5. Alkaloid fraction $(100 \mu \mathrm{g})$, and 6. physostigmine $(0.05 \mu \mathrm{g})$. TLC elution system: $\mathrm{CHCl}_{3} / \mathrm{MeOH} / \mathrm{NH}_{4} \mathrm{OH}(90: 7.5: 2.5 \mathrm{v} / \mathrm{v})$.

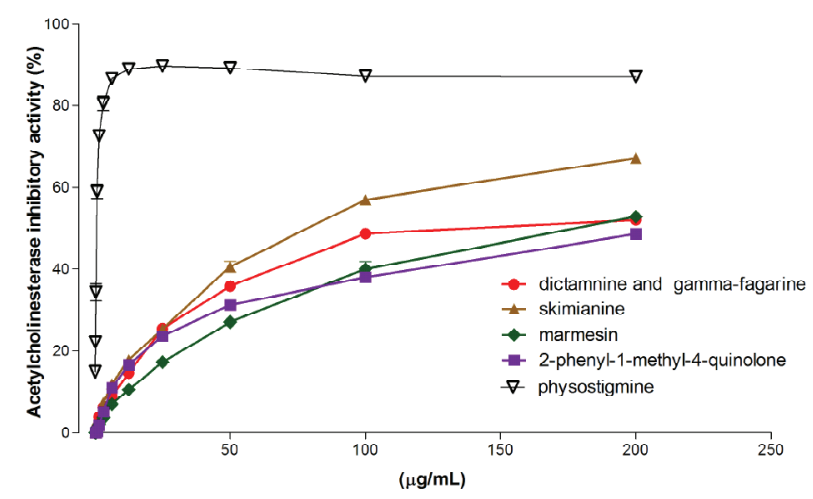

Figure 4. Quantitative evaluation of the anticholinesterase activity of the purified compounds ( 0.78 to $200 \mu \mathrm{g} / \mathrm{mL}$ ), compared with the standard physostigmine.

Comparatively, alkaloid skimmianine (3) showed to be more active in the AChE quantitative assay with IC50 $74.09 \pm 0.33 \mathrm{mg} / \mathrm{mL}$. However, despite of the interesting potential detected to compound 3, this result was higher than that calculated to positive control physostigmine (IC50 $0.61 \pm 0.037 \mu \mathrm{g} / \mathrm{mL}$ ). Skimianine (3) was isolated from alkaloid fraction of Esenbeckia leiocarpa, and showed weaker inhibitory potential (IC50 $1.4 \mathrm{mM}$ or $362.6 \mu \mathrm{g} / \mathrm{mL}$ ) when compared to reference compounds (Cardoso-Lopes et al., 2010). In this same work, the authors evaluated the AChE inhibitory activity of compounds obtained from alkaloid fraction from stems of Esenbeckia leiocarpa (Rutaceae), being the more active leptomerine (IC50 $2.5 \mu \mathrm{M}$ ), with potential close to the reference compounds physostgmine (IC50 $0.4 \mu \mathrm{M}$ ) and galantamine (IC50 1.7 $\mu \mathrm{M}$ ). Comparatively, leptomerine showed a similar structure of compound 4, which among the isolated alkaloids, showed the lower potential. Thus, the obtained data suggested that the promising inhibitory potential of leptomerine could be

Table 2. Acetylcholinesterase inhibitory potential of the purified compounds $(0.78$ to $200 \mu \mathrm{g} / \mathrm{mL})$.

\begin{tabular}{cccccc}
\hline \multirow{2}{*}{$\begin{array}{c}\text { Concentration } \\
(\mu \mathrm{g} / \mathrm{mL})\end{array}$} & $\begin{array}{c}\text { Dictamnine plus } \\
\gamma \text {-Fagarine }\end{array}$ & Skimianine & Marmesin & $\begin{array}{c}\text { 2-Phenyl-1-methyl- } \\
\text { 4-quinolone }\end{array}$ & Physostigmine \\
\cline { 2 - 6 } & $\begin{array}{c}\text { \% of } \\
\text { inhibition } \pm \text { SEM }\end{array}$ & $\begin{array}{c}\text { \% of } \\
\text { inhibition } \pm \text { SEM }\end{array}$ & $\begin{array}{c}\% \text { of } \\
\text { inhibition } \pm \text { SEM }\end{array}$ & $\begin{array}{c}\% \text { of } \\
\text { inhibition } \pm \text { SEM }\end{array}$ & $\begin{array}{c}\% \text { of } \\
\text { inhibition } \pm \text { SEM }\end{array}$ \\
\hline 0,78 & $1.449 \pm 0,314$ & $0,985 \pm 0,259$ & $1.285 \pm 0,662$ & $0,347 \pm 0,096$ & $58.976 \pm 0,91$ \\
1,56 & $3.802 \pm 0,529$ & $3.12 \pm 0,379$ & $2.064 \pm 0,425$ & $1.839 \pm 0,376$ & $72.639 \pm 0,324$ \\
3,12 & $6.131 \pm 0,665$ & $7.295 \pm 0,498$ & $3.584 \pm 0,061$ & $5.041 \pm 0,315$ & $80.540 \pm 1,032$ \\
6,25 & $8.876 \pm 0,193$ & $11.98 \pm 0,598$ & $6.954 \pm 0,657$ & $11.060 \pm 0,407$ & $86.671 \pm 0,124$ \\
12,50 & $14.622 \pm 0,798$ & $17.780 \pm 0,154$ & $10.550 \pm 0,272$ & $16.597 \pm 0,494$ & $89.066 \pm 0,174$ \\
25,00 & $25.507 \pm 0,601$ & $25.398 \pm 0,363$ & $17.194 \pm 0,357$ & $23.742 \pm 0,344$ & $89.736 \pm 0,121$ \\
50,00 & $35.822 \pm 0,886$ & $40.562 \pm 0,786$ & $27.089 \pm 0,574$ & $31.237 \pm 0,673$ & $89.296 \pm 0,147$ \\
100,00 & $48.652 \pm 0,503$ & $57.026 \pm 0,323$ & $39.985 \pm 1,073$ & $37.928 \pm 0,217$ & $87.296 \pm 0,085$ \\
200,00 & $52.002 \pm 0,203$ & $67.213 \pm 0,298$ & $52.869 \pm 0,257$ & $48.606 \pm 0,235$ & $87.158 \pm 0,401$ \\
\hline
\end{tabular}


explained by structural difference, since the compound 4 contains a phenyl substituent in place of n-propyl.

In this paper, the IAChE property of extracts, fractions and purified compounds from the stems of $C$. fontanesianus as well as the identification of dictamnine, $\gamma$-fagarine, skimianine, 2-phenyl-1-methyl4-quinolone and marmesin, already isolated from other species of the family Rutaceae, are herein reported for the first time. As previously mentioned, the search for new compounds which could act as inhibitor of AChE from Brazilian vegetal species is of great interest, since some of the substances already used as medicine for the treatment of Alzheimer's, present limitations such as low bioavailability and high hepatotoxicity.

\section{Acknowledgment}

This work was supported by the Brazilian research funding agencies Conselho Nacional de Desenvolvimento Científico e Tecnológico, Fundação de Amparo à Pesquisa do Estado de São Paulo and Coordenação de Aperfeiçoamento de Pessoal de Nível Superior. The authors thank Mary Pereira Monteiro (IBt) for technical support.

\section{References}

Abu-Mustafa EA, Fayez MBE 1961. Natural coumarins. I. Marmesin and marmesinin, further products from the fruits of Ammi majus L. J Org Chem 26: 161-166.

Agripino DG, Lima MEL, Silva MR, Meda CI, Bolzani VS, Cordeiro I, Young MCM, Moreno PRH 2004. Screening of Brazilian plants for antimicrobial and DNA-damaging activities. I. Atlantic rain forest ecological station Juréia-Itatins. Biota Neotrop 4: $1-15$.

Ambrozin ARP, Vieira PC, Fernandes JB, Fernandes MFG 2008. Piroflavonas inéditas e atividades tripanomicidas das substâncias isoladas de Conchocarpus heterophyllus. Quim Nova 31: 740-743.

Barbosa-Filho JM, Medeiros KCP, Diniz MF, Batista LM, Athayde-Filho PF, Silva MS, Cunha EVL, Almeida JRGS, Quintans-Júnior LJ 2006. Natural products inhibitors of the enzyme acetylcholinesterase. Rev Bras Farmacogn 16: 258-285.

Biavatti MW, Vieira PC, Silva MFGF, Fernandes JB, Victor SR, Pagnocca FC, Albuquerque S, Caracelli I, ZukermanSchpector J 2002. Biological activity of quinoline alkaloids from Raulinoa echinata and X-ray structure of flindersiamine. J Braz Chem Soc 13: 66-70.

Cardoso-Lopes EM, Maier JA, Silva MR, Regasini O, Simote SY, Lopes NP, Pirani JR, Bolzani VS, Young MCM 2010. Alkaloids from stems of Esenbeckia leiocarpa Engl. (Rutaceae) as potential treatment for Alzheimer disease. Molecules 15: 9205-9213.
Cortez LER, Cortez DAG, Ferreira AG, Vieira PC, Silva MFGF, Fernandes JB 2006. Constituintes químicos de Almeida coerulata (Nees \& Mart.) A. St.-Hil. Rutaceae. Rev Bras Farmacogn 16: 164-169.

Cortez LER, Cortez DAG, Fernandes JB, Vieira PC, Ferreira AG, Silva MFGF 2009. New alkaloids from Conchocarpus gaudichaudianus. Heterocycles 78: 1-7.

Ellman GL, Courtney KD, Andres VJr, Featherstone RM 1961. A new and rapid colorimetric determination of acetylcholinesterase activity. Biochem Pharmacol 7: 88-95.

Francis PT, Palmer AM, Snape M, Wilcock GK 1999. The cholinergic hypothesis of Alzheimer disease: A rewiew of progress. J Neurol Neurosur Psychiatry 66: 137147.

Grundon MF, McCorkindale NJ 1957. The synthesis of dictamnine and $\gamma$-fagarine. Synthesis 417: 2177-2185.

Guela C, Mesulam MM 1994. Cholinergic systems and related neuropathological predilection patterns in Alzheimer disease. In: Terry RD, Katzman R, Bick KL (org.) Alzheimer Disease. New York: Raven Press, p. 263291.

Houghton PJ, Ren Y, Howes MJ 2006. Acetylcholinesterase inhibitors from plants and fungi. Nat Prod Rep 23: 181199.

Howes MJR, Perry NSL, Houghton PJ 2003. Plants with traditional uses and activities, relevant to the management of Alzheimer's disease and other cognitive disorders. Phytother Res 17: 1-18.

Inada A, Ogasawara R, Koga I, Nakatani N, Inatomi Y, Murata H, Nishi M, Nakanishi T 2008. Three new furoquinoline alkaloids from the leaves of Boninia glabra. Chem Pharm Bull 56: 727-729.

Joo SH, Lee SC, Kim SK 2004. UV absorbent, marmesin, from the bark of Thanakha, Hesperethusa crenulata L. J Plant Biol 47: 163-165.

Kallunki J, Pirani JR 1998. Synopses of ngostura Roem. \& Schult.and Conchocarpus J. C. Mikan (Rutaceae). Kew Bulletin 53: 257-334.

Li SG, Tian HY, Ye WC, Jiang RW 2011. Benzopyrans and furoquinoline alkaloids from Melicope pteleifolia. Biochem Syst Ecol 39: 64-67.

Marston A, Kissling J, Hostettmann K 2002. A papid TLC bioautographic method for the detection of acetylcholinesterase and butyrylcholinesterase inhibitors in plants. Phytochem Anal 13: 51-54.

Paulini H, Waibel R, Schimmer O 1989. Mutagenicity and structura-mutagenicity relationships of furoquinolines, naturally occurring alkaloids of the Rutaceae. Mutat res 227: 179-186.

Pirani JR 2002. Conchocarpus J.C. Mikan. In: Wanderley MGL, Shepherd GJ, Giulietti AM, Melhem TS, Bittrich V, Kameyama C (org.) Flora Fanerogâmica do Estado de São Paulo. São Paulo: Hucitec, p. 284-285.

Pirani JR 2010. Conchocarpus. http://floradobrasil.jbrj.gov. 
br/2010/FB000438, accessed in March 2011

Rhee IK, Meent MV, Ingkaninan K, Verpoorte R 2001. Screening for acetylcholinesterase inhibitors from Amaryllidaceae using sílica gel thin-layer chromatography in combination with bioactivity staining. J Chromatogr 915: 217-223.

Scott LJ, Goa KL 2000. Galanthamine: A review of its use in Alzheimer's disease. Drugs 60: 1095-1122.

Trevisan MTS, Macedo FVV, Meent MV, Rhee IK, Verpoorte R 2003. Seleção de plantas com atividade anticolinesterase para tratamento da doença de Alzheimer. Quim Nova 26: 301-304.

Trumble JT, Millar JG 1996. Biological activity of marmesin and demethylsuberosin against a generalist herbivore, Spodoptera exigua (Lepdoptera: Noctuidae). J Agric
Food Chem 44: 2859-2864.

Vieira PC, Kubo I, Kujime H, Yamagiwa Y, Kamikawa T 1992. Molluscicidal acridone alkaloids from Angostura paniculata: isolation, structures, and synthesis. J Nat Prod 55: 1112-1117.

\section{*Correspondence}

\section{Maria C. M. Young}

Instituto de Botânica de São Paulo (IBt/SMA)

Av. Miguel Estéfano, 3687, Água Funda, Caixa Postal 3005, 01031-970 São Paulo-SP, Brasil

mcmarxyoung@pq.cnpq.br

Tel/Fax.: +55 1150736073 